\title{
Effect of peracetic acid on biofilms formed by Listeria monocytogenes strains isolated from a Brazilian cheese processing plant
}

\author{
Sarah Hwa In Lee', Giovana Verginia Barancelli², Carlos Humberto Corassin ${ }^{1}$, Roice Eliana \\ Rosim$^{1}$, Carolina Fernanda Sengling Cebin Coppa ${ }^{1}$, Carlos Augusto Fernandes de Oliveira ${ }^{{ }^{*}}$
}

\begin{abstract}
${ }^{1}$ Department of Food Engineering, School of Animal Science and Food Engineering, University of São Paulo, Pirassununga, SP, Brazil, '2Department of Agroindustry, Food and Nutrition, "Luiz de Queiroz" College of Agriculture, University of São Paulo, Piracicaba, SP, Brazil.
\end{abstract}

\begin{abstract}
This study aimed to investigate the effect of peracetic acid (PAA, $0.5 \%$ ) on adherent cells of three strains of Listeria monocytogenes strains belonging to serotypes $4 \mathrm{~b}$ and $1 / 2 \mathrm{~b}$ that had been previously isolated from the environment of a Brazilian cheese plant. The assays were conducted using polystyrene microplates and stainless steel coupons and the adhered cells were treated with PAA for 60, 120 and $180 \mathrm{~s}$. On stainless steel, biofilms were partially inactivated by PAA after $60 \mathrm{~s}$ and almost $100 \%$ of the cells were damaged within $180 \mathrm{~s}$ using epifluorescence microscopy with LIVE/DEAD ${ }^{\circledR}$ staining. On polystyrene microplates, PAA decreased $(P<0.05)$ biofilm biomass produced by the three L. monocytogenes isolates at $60 \mathrm{~s}$, when compared with controls (no PAA treatment). However, PAA did not completely eliminate L. monocytogenes cells on polystyrene microplates (decreasing 1.8-2.5 log cycles after treatment with PAA for $180 \mathrm{~s}$ ). The correct concentration and contact time of PAA is critical for eliminating biofilms formed by L. monocytogenes on stainless steel surfaces, although further studies are needed for defining efficient PAA treatments to remove adherent cells of this pathogen on plastic polymers.
\end{abstract}

Keywords: Peracetic acid (PAA)/ biofilm/effects. L. monocytogenes. Dairy plants/Brazil.

\section{INTRODUCTION}

Listeria monocytogenes is a rod-shaped, nonspore pathogen that can be widely distributed in the environment, including soil, surface water used for agricultural purposes and food products (Casarin et al., 2014). The dairy industry is particularly susceptible to contamination by L. monocytogenes, and several cheese-associated Listeria outbreaks have been described worldwide (Johnsen et al., 2010; Koch et al., 2010). The presence of $L$. monocytogenes in the environment of cheese processing plants can be a potential source of contamination, especially when the microorganism survives in niches that are difficult to sanitize or in places where moisture and food debris are present (Tompkin, 2002). Under these circumstances, the pathogen may

\footnotetext{
*Correspondence: C. A. F. Oliveira. Departamento de Engenharia de Alimentos, Faculdade de Zootecnia e Engenharia de Alimentos, Universidade de São Paulo. Av. Duque de Caxias - Norte, 225, CEP 13635-900, Pirassununga, SP, Brazil. Tel.: +55 19 3565-4173; Fax: +55 19 3565-4284. E-mail: carlosaf@usp.br
}

spread from the processing environment thus leading to the contamination of final products through the ventilation system, dripping and splashing, or by workers (Kells, Gilmour, 2004).

Biofilms are large, complex, and organized bacterial ecosystems in which water channels are dispersed providing passages for nutrient, metabolite, and waste product exchange (Sauer, Rickard, Davies, 2007). L. monocytogenes is one of the most important foodborne pathogens that has the ability to adhere and produce biofilms on inert surfaces (Shi, Zhu, 2009; Takahashi et al., 2011). An important consequence of the protective effect provided by L. monocytogenes biofilms is the lower effectiveness of sanitizing agents against the bacterial cells, thus leading to a permanent source of contamination in the food processing facilities (Belessi et al., 2011).

Peracetic acid (PAA) is a common sanitizer used in the dairy industry (Ceragioli et al., 2010) and is normally used in food industries in Brazil at concentrations of $300-700 \mathrm{mg} / \mathrm{L}$ (Quarentei et al., 2011). PAA has a 
broad spectrum and is a strong oxidizing agent that is decomposed into safe waste products (Van der Veen, Abee, 2011). Several studies have demonstrated that PAA was efficient in removing adhered cells of L. monocytogenes (Belessi et al., 2011; Ibusquiza, Herrera, Cabo, 2011; Stoporth et al., 2002). Lee et al. (2016) also found that PAA at $0.5 \%$ was able to inactivate biofilms formed by a L. monocytogenes strain isolated from brine on stainless steel, but was not effective for removing their adherent cells on polystyrene microplates. Thus, the present study aimed to evaluate the effect of PAA at different contact times on biofilms produced on polystyrene microplates and stainless steel coupons by L. monocytogenes strains previously isolated from the environment of a Brazilian cheese plant.

\section{MATERIAL AND METHODS}

\section{L. monocytogenes Isolates}

Three L. monocytogenes isolates, which were obtained from the floor of the pasteurization room (isolates $\mathrm{A}$ and B) and cooling chamber (isolate C) of a cheese processing plant located in the northeastern region of the state of São Paulo from October 2008 to September 2009, as described by Barancelli et al. (2011) were evaluated in this study. The L. monocytogenes isolates A, B and C belonged to serotypes $4 b, 1 / 2 b$ and $1 / 2 b$, respectively. The isolates were maintained in tubes containing Tryptone Soya Broth (TSB; Oxoid, UK) broth with $15 \%$ glycerol at $-80{ }^{\circ} \mathrm{C}$ until analyses for biofilm formation ability and PAA treatments.

\section{Effect of Peracetic Acid on Biofilms Formed on Polystyrene Microplates}

The effect of PAA on adherent cells of $L$. monocytogenes isolates $\mathrm{A}, \mathrm{B}$ and $\mathrm{C}$ was evaluated by determining the biofilm-forming index (BFI) on polystyrene microplates. Assays were conducted in 4 replicates, as originally described by Srey et al. (2014), with modifications proposed by Lee et al. (2016). One loop of each isolate stored in TSB with $15 \%$ glycerol was added to $5 \mathrm{~mL}$ of freshly prepared TSB, incubated at $37^{\circ} \mathrm{C}$ for $24 \mathrm{~h}$ and diluted until reaching 0.5 on the McFarland scale (approximately $10^{8}$ cells $/ \mathrm{mL}$ ). Triplicate aliquots $(200 \mu \mathrm{L})$ of each TSB bacterial suspension were transferred into 3 wells of a flat bottomed, 96-well polystyrene microplate and incubated statically at $35^{\circ} \mathrm{C}$ for $48 \mathrm{~h}$. After incubation, the OD values of bacterial suspensions in the microplate wells were measured in a microtiter plate reader (Labsystems, MultiSkan, USA) at $600 \mathrm{~nm}$. Planktonic cells and the medium were removed, and each well was rinsed three times with $250 \mu \mathrm{L}$ of phosphate buffer saline (PBS) to remove loosely attached cells. Then $250 \mu \mathrm{L}$ of PAA $(0.5 \%, \mathrm{pH}: 2.3)$ (Dinâmica, Brazil) was added and allowed to react for 60, 120 and 180 $\mathrm{s}$. The concentration of PAA $(0.5 \%)$ used was the same as described by Lee et al. (2016), who showed that PAA was able to inactivate biofilms formed by a L. monocytogenes strain isolated from brine on stainless steel. At the end of each treatment period, the disinfectant was removed and $250 \mu \mathrm{L}$ of sodium thiosulfate $0.1 \mathrm{M}$ (Chemco, Brazil) was added to each well for 5 min to stop the reaction. Instead of the disinfectant, PBS was used for treating the positive control (well with bacterial biofilm of each isolate tested not subjected to any disinfectant challenge) and negative control (well with non-inoculated TSB). Finally, wells were rinsed three times with $250 \mu \mathrm{L}$ PBS.

Biofilms were fixed with $250 \mu \mathrm{L}$ methanol (Synth, Brazil) for $15 \mathrm{~min}$. Plates were dried in inverse position for $30 \mathrm{~min}$, and then $250 \mu \mathrm{L}$ crystal violet dye $0.1 \%$ (Synth, Brazil) was added and let set for for $15 \mathrm{~min}$ to stain the biofilm, positive control, and negative control wells. The stain was removed by pipetting, and the plate was rinsed with distilled water until the washing water was dye free and then air-dried for at least $2 \mathrm{~h}$. The bound dye was resolubilized in 95\% ethanol (Synth, Brazil) for $30 \mathrm{~min}$ and transferred into a new plate. The OD of the dye solution was measured at $570 \mathrm{~nm}\left(\mathrm{OD}_{570 \mathrm{~nm}}\right)$. Biofilm-removing efficacy at the different PAA contact times was compared using the BFI calculated with the following formula (Niu, Gilbert, 2004):

$$
\mathrm{BFI}=\frac{\left(\mathrm{OD}_{570 \mathrm{~nm}}-\mathrm{OD}_{\mathrm{C570 \textrm {nm }}}\right)}{\left(\mathrm{OD}_{600 \mathrm{~nm}}-\mathrm{OD}_{\mathrm{C} 600 \mathrm{~nm}}\right)}
$$

where $\mathrm{OD}_{570 \mathrm{~nm}}$ was obtained from the disinfected (treated) or positive control (biofilm treated with PBS) wells after staining, and the $\mathrm{OD}_{\mathrm{C} 570 \mathrm{~nm}}$ was obtained from the negative control wells (TSB wells treated with PBS) after staining. $\mathrm{OD}_{600 \mathrm{~nm}}$ was obtained from the disinfected or positive control wells, and $\mathrm{OD}_{\mathrm{C} 600 \mathrm{~nm}}$ was obtained from negative control wells after 48-h biofilm formation.

The efficiency of PAA against the biofilms was also evaluated by culturable cell counts in each well of the microplates, following the procedures recommended by Srey et al. (2014). Another set of triplicate aliquots of $200 \mu \mathrm{L}$ of each TSB bacterial suspension were transferred into 3 wells of a flat bottomed, 96-well polystyrene microplate and incubated statically at $35^{\circ} \mathrm{C}$ for $48 \mathrm{~h}$. After incubation, all planktonic cells and medium were removed and the wells were rinsed three times with 250 
$\mu \mathrm{L}$ of PBS. Each well was treated with PAA for 60,120 and $180 \mathrm{~s}$ as mentioned above. After the PAA contact times, the sanitizer was removed from each well and 250 $\mu \mathrm{L}$ sodium thiosulfate $0.1 \mathrm{M}$ (Chemco, Brazil) was placed into each well. Then, a sterile cotton swab was pressed to the bottom of the well and rotated 50 times clockwise and another 50 times counterclockwise (Srey et al., 2014). Swabs were placed in test tubes containing sterilized PBS. Tubes were left to rest for $5 \mathrm{~min}$, and then were vortexed for $30 \mathrm{~s}$ each. After that, the contents of the tubes were subjected to serial dilutions for spread plating on modified Oxford Agar (Oxoid, UK). Plates were incubated at $37^{\circ} \mathrm{C}$ for $48 \mathrm{~h}$ before counting. Results were expressed as colony forming units per well (CFU/well).

\section{Effect of peracetic acid on biofilms formed on stainless steel}

The ability to produce biofilms on stainless steel was evaluated by epifluorescence microscopy using calcofluor white dye (Sigma-Aldrich, Saint Louis, MO). Stainless steel coupons $(1.0 \times 1.0 \mathrm{~cm})$ were placed in the bottom of wells of a 24-well flat-bottomed plastic microplate, and $2 \mathrm{~mL}$ of each TSB bacterial suspension (nearly $10^{8}$ cells/ $\mathrm{mL}$, or 0.5 in McFarland scale) was pipetted into a series of three wells. After incubation at $35^{\circ} \mathrm{C}$ for $48 \mathrm{~h}$ without stirring, the stainless-steel coupons were removed from each well with sterile forceps, rinsed with sterile PBS buffer, and placed in sterile tubes. Right before treatment, $2.0 \%$ PAA was diluted to $0.5 \%$ with sterile distilled water. Contact times were $0,60,120$ and $180 \mathrm{~s}$. Two mL of PAA was added for each contact time and the reaction was stopped by adding $6 \mathrm{~mL}$ of sodium thiosulfate solution for 5 minutes. After the determined contact time, tubes were emptied, and stainless steel coupons were removed from each tube with sterile forceps, and finally placed on glass slides.

The viability of surface-bound bacteria was examined using the L7007 LIVE/DEAD ${ }^{\circledR}$ Baclight kit (Molecular Probes, US), which contains SYTO 9 and propidium iodide dyes that are usually applied to suspended bacteria. Therefore $30 \mu \mathrm{L}$ of LIVE/DEAD ${ }^{\circledR}$ Baclight was applied directly to the adhered bacteria on stainless steel. After 10 minutes of incubation the effects of the PAA treatments on biofilms on stainless steel coupons were examined on an epifluorescence microscope (Nikon Eclipse N1-U 80i with camera software NIS Elements AR 4.13.01 64 bit, 4.0, Tokyo, Japan). All treatments were conducted in duplicate, and the comparison of the results was made with the negative control (biofilm formation without any treatment of each bacterium on stainless steel).

\section{Statistical analysis}

BFI values and colony counts (Log-transformed) obtained in the polystyrene microplate assays with PAA were analyzed by one-way analysis of variance using the Statistical Analysis System (SAS, 2002). The means for treatments showing significant differences were compared using the Tukey test, considering $P<0.05$.

\section{RESULTS AND DISCUSSION}

BFI values and their respective percentage reductions of biofilm-producing L. monocytogenes isolates on polystyrene microplates after treatment with PAA $(0.5 \%)$ for different contact times are presented in Table I. BFI values of the three isolates decreased $(P<0.05)$ after 60 $\mathrm{s}$ treatment, although there were no differences $(P>0.05)$ between the treatment times for isolate $\mathrm{A}$. Isolates $\mathrm{B}$ and $\mathrm{C}$ had lower BFI at $180 \mathrm{~s}$, which was consistent with their higher percentage reductions $(P<0.05)$ at this time when compared with values obtained at 60 or $120 \mathrm{~s}$. The isolate A belonged to serotype $4 \mathrm{~b}$, which is of great public health importance since this serotype is frequently involved in outbreaks of human listeriosis (Graves, Swaminathan, Hunter, 2007). Although in the present study the BFI values for isolate A (serotype $4 \mathrm{~b}$ ) were lower than for isolates B or $\mathrm{C}$ (serotype $1 / 2 \mathrm{~b}$ ) at all treatment times, the available data relating phylogenetic division, serotype, and biofilm formation remained inconclusive (Djordjevic, Wiedmann, Mclandsborough, 2002; Borucki et al., 2003). In a recent report by Wang et al. (2016), the biofilm-formation ability of serotype $1 / 2$ b was higher than serotype $1 / 2 a$, which is consistent with data presented in this study. However, the large variability of data reported in the literature indicates that biofilm formation of $L$. monocytogenes is strain dependent, since no clear correlation with serotypes could be established thus far (Doijad et al., 2015). Importantly, no treatment was able to completely reduce the BFI value of the biofilm producers evaluated, with percentage reduction varying from 29.3 to $62.3 \%$. Lee et al. (2016) also reported that PAA was not effective for removing adherent cells of a L. monocytogenes strain isolated from brine on polystyrene microplates.

Biofilms of Listeria have been shown to be much more resistant to stress and to sanitizing agents than planktonic cells (Chavant, Gaillard-Martine, Hebraud, 2004). It is believed that biofilm formation enhances the capacity of foodborne bacteria to survive stressors that are commonly found in the food-processing environment (e.g. refrigeration, acidity, salinity, disinfection) (Giaouris et al., 2012). The mechanisms involved in the increased 
TABLE I - Biofilm-forming index (BFI) and respective percentage reduction of biofilm-producing L. monocytogenes isolates (A-Cl) on polystyrene microplates, after treatments with peracetic acid $(0.5 \%)$ at different contact times ${ }^{2}$

\begin{tabular}{lcccccc}
\hline \multirow{2}{*}{ Time (s) } & \multicolumn{2}{c}{ Isolate A } & \multicolumn{2}{c}{ Isolate B } & \multicolumn{2}{c}{ Isolate C } \\
\cline { 2 - 7 } & BFI & \% Reduction $^{\mathbf{3}}$ & BFI & \% Reduction $^{3}$ & BFI & \% Reduction $^{3}$ \\
\hline 0 & $0.38 \pm 0.06^{\mathrm{a}}$ & - & $0.77 \pm 0.06^{\mathrm{a}}$ & - & $0.58 \pm 0.06^{\mathrm{a}}$ & - \\
60 & $0.16 \pm 0.02^{\mathrm{b}}$ & $57.8 \pm 0.1^{\mathrm{a}}$ & $0.46 \pm 0.05^{\mathrm{b}}$ & $40.2 \pm 0.1^{\mathrm{b}}$ & $0.41 \pm 0.05^{\mathrm{b}}$ & $29.3 \pm 0.1^{\mathrm{b}}$ \\
120 & $0.19 \pm 0.05^{\mathrm{b}}$ & $50.0 \pm 0.1^{\mathrm{a}}$ & $0.44 \pm 0.08^{\mathrm{b}}$ & $42.8 \pm 0.1^{\mathrm{b}}$ & $0.38 \pm 0.06^{\mathrm{b}}$ & $34.3 \pm 0.1^{\mathrm{b}}$ \\
180 & $0.15 \pm 0.06^{\mathrm{b}}$ & $60.5 \pm 0.1^{\mathrm{a}}$ & $0.29 \pm 0.08^{\mathrm{c}}$ & $62.3 \pm 0.1^{\mathrm{a}}$ & $0.26 \pm 0.08^{\mathrm{c}}$ & $55.1 \pm 0.1^{\mathrm{a}}$ \\
\hline
\end{tabular}

${ }^{1}$ Isolates A, B and C were classified as serotypes $4 \mathrm{~b}, 1 / 2 \mathrm{~b}$ and $1 / 2 \mathrm{~b}$, respectively. ${ }^{2}$ Data are reported as mean \pm standard deviation of 4 replicates. ${ }^{3}$ Relative to the initial BFI before treatment with peracetic acid (time: $0 \mathrm{~s}$ ). ${ }^{\text {a-c }}$ Values within each column with different superscript letters differ significantly $(P<0.05)$.

resistance of biofilms to antimicrobial agents are not completely understood, although restricted penetration into the biofilm, slow growth rate of biofilm organisms and induction of resistance mechanisms have been postulated (Donlan, Costerton, 2002). Van der Veen, Abee (2011) demonstrated that L. monocytogenes biofilms are more resistant than planktonic cells to peracetic acid treatments, which corroborates the low effect of PAA treatment observed on culturable cells of $L$. monocytogenes isolated from cheese processing plants in Brazil.

The limited effect of PAA on the biofilms produced by the L. monocytogenes isolates on polystyrene microplates was confirmed by culturable cell counts, and is presented in Table II. Similar to the BFI variation after PAA treatment, counts were lower $(P<0.05)$ when compared with initial counts $(5.5 \pm 0.3$ to $5.6 \pm 0.6 \log$ $\mathrm{CFU} /$ well), but decreased only 1.8-2.5 log cycles. It should be noted that the BFI method and the culturable cell count method may provide two completely different results. The BFI method enables an estimation of the biofilm mass composed of cells and extracellular polymeric substances (EPS) that attach to a surface. However, it does not provide information on the biological status of the cells. On the other hand, culturable cell counts enable the evaluation of the bactericidal effect of the disinfectants on the biofilm (Srey et al., 2014). Destruction of existing biofilms can involve removing the intact biofilm from surfaces via mechanical action for instance, or dissolving the biofilm structure by chemical disruption of EPS, for example. These mechanisms do not necessarily kill bacteria (Chan, Abedon, 2015).

On stainless steel, the biofilms formed by the three $L$. monocytogenes isolates were affected by PAA $(0.5 \%)$ after $60 \mathrm{~s}$, with almost 100\% cell damage within $180 \mathrm{~s}$, as shown in Figure 1. Similar results were observed by Lee et al. (2016), indicating that PAA $(0.5 \%)$ was able to inactivate the biofilm of L. monocytogenes formed on stainless steel. Our results are also in agreement with those reported by Ibusquiza, Herrera and Cabo (2011), who observed that PAA treatment for $10 \mathrm{~min}$ was effective in eliminating $L$. monocytogenes biofilms. The authors considered that the high oxidizing capacity and low molecular size of PAA are advantages for biofilm penetration.

In the present experiment, PAA was more effective against $L$. monocytogenes biofilms than other compounds evaluated in previous reports, such as benzalkonium

TABLE II - Culturable cell counts and respective reductions of biofilm-producing L. monocytogenes isolates (A-C ) on polystyrene microplates, after treatments with peracetic acid $(0.5 \%)$ at different contact times ${ }^{2}$

\begin{tabular}{lllllll}
\hline \multirow{2}{*}{ Time (s) } & \multicolumn{2}{l}{ A $($ Log CFU/well) } & \multicolumn{2}{l}{ B (Log CFU/well) } & \multicolumn{2}{l}{ C (Log CFU/well) } \\
\cline { 2 - 7 } & Count & Reduction $^{3}$ & Count & Reduction $^{3}$ & Count & Reduction $^{3}$ \\
\hline 0 & $5.5 \pm 0.3^{\mathrm{a}}$ & - & $5.6 \pm 0.4^{\mathrm{a}}$ & - & $5.6 \pm 0.6^{\mathrm{a}}$ & - \\
60 & $3.1 \pm 0.3^{\mathrm{b}}$ & $2.3 \pm 0.3^{\mathrm{a}}$ & $3.6 \pm 0.7^{\mathrm{b}}$ & $2.1 \pm 0.7^{\mathrm{a}}$ & $3.4 \pm 0.8^{\mathrm{b}}$ & $2.2^{\mathrm{b}} \pm 0.8^{\mathrm{a}}$ \\
120 & $3.3 \pm 0.2^{\mathrm{b}}$ & $2.1 \pm 0.2^{\mathrm{a}}$ & $3.6 \pm 0.7^{\mathrm{b}}$ & $2.1 \pm 0.7^{\mathrm{a}}$ & $3.5 \pm 0.4^{\mathrm{b}}$ & $2.4^{\mathrm{b}} 0.4^{\mathrm{a}}$ \\
180 & $3.6 \pm 0.5^{\mathrm{b}}$ & $1.8 \pm 0.5^{\mathrm{a}}$ & $3.1 \pm 0.2^{\mathrm{b}}$ & $2.5 \pm 0.2^{\mathrm{a}}$ & $3.2 \pm 0.4^{\mathrm{b}}$ & $2.4^{\mathrm{b}} \pm 0.4^{\mathrm{a}}$ \\
\hline
\end{tabular}

${ }^{1}$ Isolates A, B and C were classified as serotypes $4 \mathrm{~b}, 1 / 2 \mathrm{~b}$ and $1 / 2 \mathrm{~b}$, respectively. ${ }^{2}$ Data are reported as mean \pm standard deviation of 4 replicates. ${ }^{3}$ Relative to the initial BFI before treatment with peracetic acid (time: $0 \mathrm{~s}$ ). ${ }^{\text {acc }}$ Values within each column with different superscript letters differ significantly $(P<0.05)$. 
A

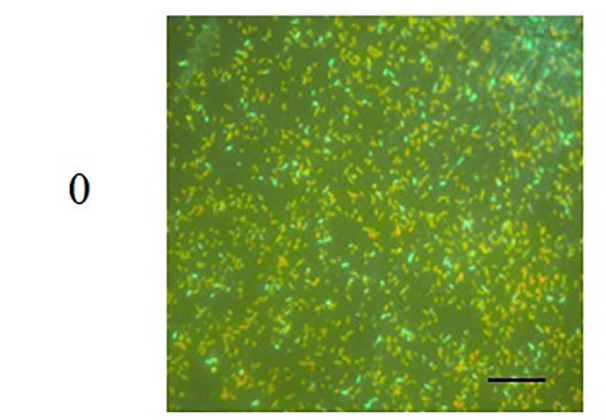

$60 \mathrm{~s}$

120 s

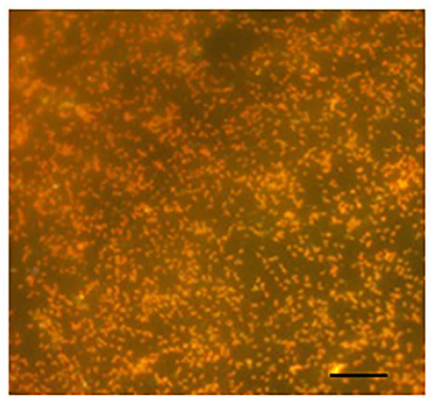

$180 \mathrm{~s}$
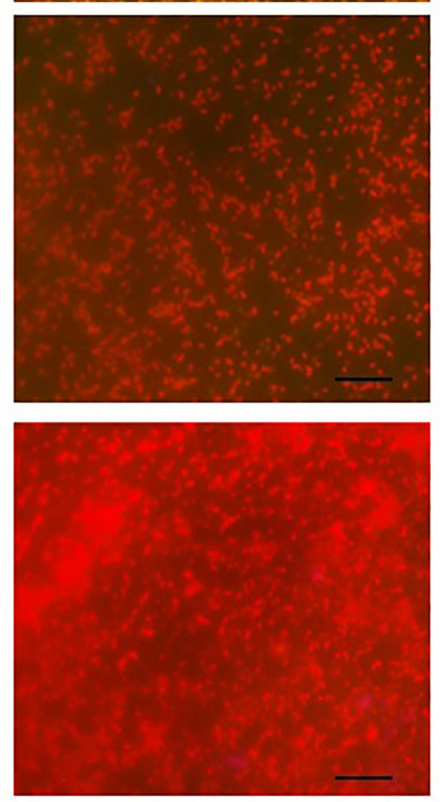

$\mathrm{B}$
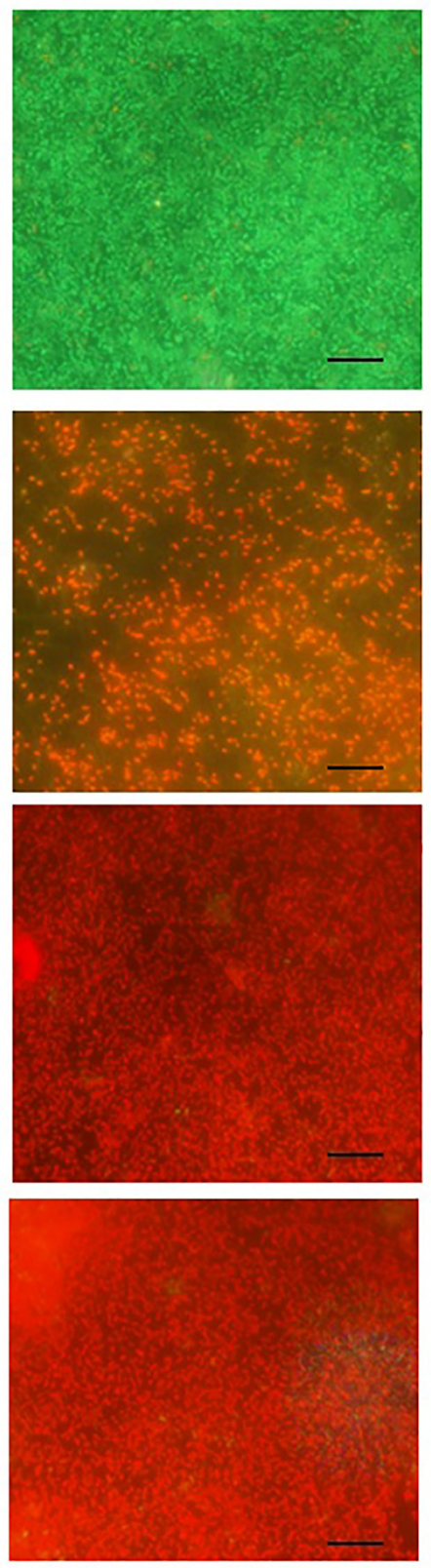

$\mathrm{C}$
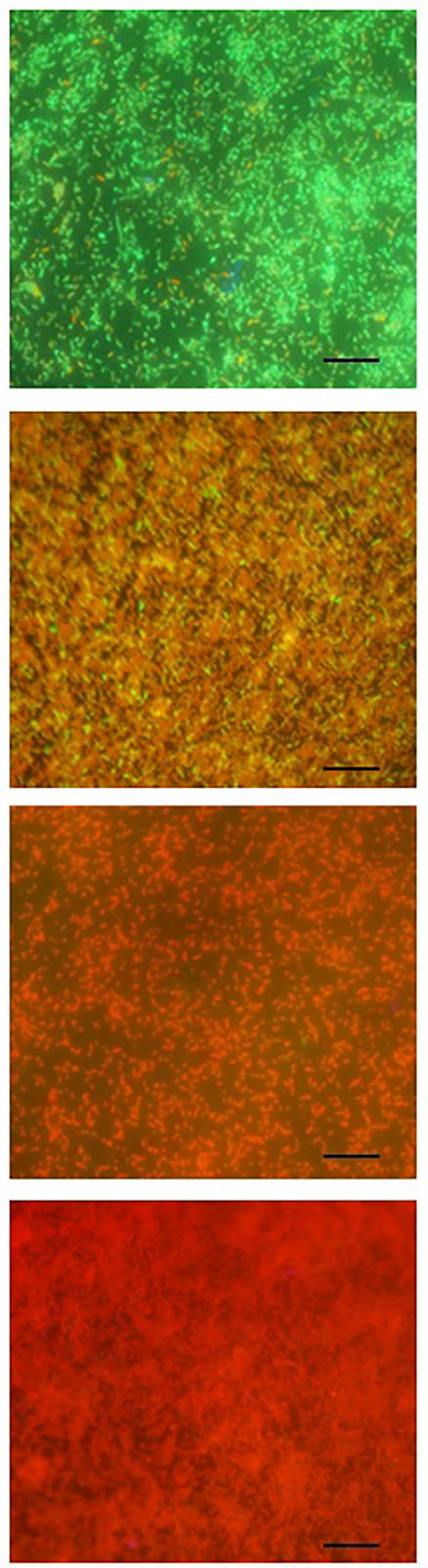

FIGURE 1 - Epifluorescence photomicrographs of biofilms formed by biofilm-producing L. monocytogenes isolates on stainless steel surfaces for 48 hours at $35^{\circ} \mathbf{C}$, after treatment with peracetic acid $(0.5 \%, v / v)$ at 60,120 and $180 \mathrm{~s}$. Isolates A, B and C were classified as serotypes $4 b, 1 / 2 b$ and $1 / 2 b$, respectively. Biofilms were stained with bacterial viability kit LIVE/DEAD ${ }^{\circ}$ BacLight (Molecular Probes, US), in which viable cells are fluorescent green (Syto 9) and non-viable cells are fluorescent red (propidium iodide). Magnification: 1,000x. Bar $=10 \mu \mathrm{m}$.

chloride or nisin (Fatemi, Frank, 1999; Stoporth et al., 2002). Similarly, Belessi et al. (2011) also found a significant reduction in the number of L. monocytogenes attached cells with increasing contact times (from 1 to 6 min) with PAA $(2.0 \%)$ on stainless steel coupons. The inhibitory effect of organic acids depends upon several factors, such as decreasing $\mathrm{pH}$, the ratio of undissociated forms of the acid entering into bacteria to inhibit metabolic activities, and chain length (Doores, 1993). It is also known that weak organic acids are lipophilic and penetrate the plasma membrane and acidifying the interior of the cell (Booth, Kroll, 1989).

The physical-chemical properties of the surfaces can influence the bacterial adhesion, since they readily adhere 
to hydrophobic surfaces such as polystyrene and stainless steel, when compared to hydrophilic materials like glass (Donlan, Costerton, 2002). Pagedar, Singh and Batish (2010) observed that $S$. aureus cells had higher capacity to form biofilms on polystyrene than stainless steel, suggesting that hydrophobicity was an important factor in the formation of the biofilms, which is in agreement with the differences in the PAA efficiency on polystyrene and stainless steel surfaces as observed in the present study. The survival of L. monocytogenes adhered cells after treatment with PAA at $0.5 \%(5,000 \mathrm{mg} / \mathrm{L})$, which is nearly ten times over the concentrations normally used in food industries $(300-700 \mathrm{mg} / \mathrm{L})$, indicate the magnitude of risk posed by a potential failure in cleaning and disinfection procedures, including the possibility of L. monocytogenes persistence in the food processing environment.

\section{CONCLUSION}

Although PAA $(0.5 \%)$ was able to inactivate the three L. monocytogenes isolates on stainless steel, it only reduced 1.8-2.5 log cycles of culturable cells on polystyrene microplates. Further studies on the factors affecting the resistance of L. monocytogenes biofilms against sanitizers are needed for defining efficient treatments with organic acids such as PAA to remove adherent cells of this pathogen.

\section{ACKNOWLEDGEMENTS}

The authors thank the Conselho Nacional de Desenvolvimento Científico e Tecnológico (CNPq, Grant 309348/2013-7), for financial support.

\section{COMPETING INTERESTS}

The authors declare that there is no conflict of interest.

\section{REFERENCES}

Barancelli GV, Camargo TM, Reis CMF, Porto E, Hofer E, Oliveira CAF. Incidence of Listeria monocytogenes in cheese manufacturing plants from the northeast region of São Paulo, Brazil. J Food Protect. 2011;74(5):816-819.

Belessi CEA, Gounadaki AS, Psomas AN, Skandamis PN. Efficiency of different sanitation methods on Listeria monocytogenes biofilms formed under various environmental conditions. Int J Food Microbiol. 2011;145(Suppl 1):S46-S52.
Booth IR, Kroll RG. The preservation of foods by low $\mathrm{pH}$. In: Gould GW. Mechanisms of action of food preservation procedures. London: Elsevier; 1989. p. 119-160.

Borucki MK, Peppin JD, White D, Loge F, Call DR. Variation in biofilm formation among strains of Listeria monocytogenes. Appl Environ Microbiol. 2003;69(12):7336-7342.

Casarin LS, Brandelli A, Casarin FO, Soave PA, Wanke CH, Tondo EC. Adhesion of Salmonella Enteritidis and Listeria monocytogenes on stainless steel welds. Int J Food Microbiol. 2014;191:103-108.

Ceragioli M, Mols M, Moezelaar R, Ghelardi E, Senesi S, Abee T. Comparative transcriptomic and phenotypic analysis of the responses of Bacillus cereus to various disinfectant treatments. Appl Environ Microbiol. 2010;76(10):3352-3360.

Chan BK, Abedon ST. Bacteriophages and their enzymes in biofilm control. Curr Pharm Design. 2015;21(1):85-99.

Chavant P, Gaillard-Martine B, Hebraud M. Antimicrobial effects of sanitizers against planktonic and sessile Listeria monocytogenes cells according to the growth phase. FEMS Microbiol Lett. 2004;236(2):241-248.

Djordjevic D, Wiedmann M, Mclandsborough LA. Microtiter plate assay for assessment of Listeria monocytogenes biofilm formation. Appl Environ Microbiol. 2002;68(6):2950-2958.

Doijad SP, Barbuddhe SB, Garg S, Poharkar KV, Kalorey DR, Kurkure NV, Rawool DB, Chakraborty T. Biofilm-forming abilities of Listeria monocytogenes serotypes isolated from different sources. PLoS One. 2015;10(9):e0137046.

Donlan RM, Costerton JM. Biofilms: survival mechanisms on clinically relevant microorganisms. Clin Microbiol Rev. 2002;15(2):167-193.

Doores S. Organic acids. In: Davidson PM, Branen AL, editors. Antimicrobials in foods. New York: Marcel Dekker; 1993. p. 95-136.

Fatemi P, Frank JF. Inactivation of Listeria monocytogenes/ Pseudomonas biofilms by peracid sanitizers. J Food Protect. 1999;62(7):761-765. 
Giaouris E, Chorianopoulos N, Skandamis P, Nychas GJ. Attachment and biofilm formation by Salmonella in food processing environments. In: Mahmoud BSM. Salmonella: A dangerous foodborne pathogen. Rijeka: Intech Open Access Publisher; 2012. p. 157-180.

Graves LM, Swaminathan B, Hunter SB. Subtyping Listeria monocytogenes. In: Ryser ET, Marth EH. Listeria, Listeriosis and food safety. 3rd ed. Boca Raton: CRC Press; 2007. p. 283304.

Ibusquiza PS, Herrera JJR, Cabo ML. Resistance to benzalkonium chloride, peracetic acid and nisin during formation of mature biofilms by Listeria monocytogenes. Food Microbiol. 2011;28(3):418-425.

Johnsen BO, Lingaas E, Torfoss D, Strom EH, Nordoy I. A large outbreak of Listeria monocytogenes infection with short incubation period in a tertiary care hospital. J Infection. 2010;61(6):465-470.

Kells J, Gilmour A. Incidence of Listeria monocytogenes in two milk processing environments, and assessment of Listeria monocytogenes blood agar for isolation. Int J Food Microbiol. 2004;91(2):167-174.

Koch J, Dworak R, Prager R, Becker B, Brockman S, Wicke A, Wichmann-Schauer H, Hof H, Werber D, Stark K. Large listeriosis outbreak linked to cheese made from pasteurized milk, Germany, 2006-2007. Foodborne Pathog Dis. 2010;7(12):15811584.

Lee SH, Cappato LP, Corassin CH, Cruz AG, Oliveira CAF. Effect of peracetic acid on biofilms formed by Staphylococcus aureus and Listeria monocytogenes isolated form dairy plants. J Dairy Sci. 2016;99(3):2384-2390.

Niu C, Gilbert ES. Colorimetric method for identifying plant essential oil components that affect biofilm formation and structure. Appl Environ Microbiol. 2004;70(12):6951-6956.

Pagedar A, Singh J, Batish VK. Surface hydrophobicity, nutritional contents affect Staphylococcus aureus biofilms and temperature influences its survival in performed biofilms. J Basic Microb. 2010;50(Suppl 1):S98-S106.
Quarentei SS, Aquino S, Germano MIS, Germano PML. Princípios gerais de higienização. In: Germano PML, Germano MIS, editores. Higiene e vigilância sanitária de alimentos. $4^{\mathrm{a}}$ ed. Barueri, SP: Editora Manole; 2011. p. 631-667.

SAS Institute. User's guide for SAS software navigator. 9th ed. SAS Institute, Cary, NY, 2002.

Sauer K, Rickard A, Davies DG. Biofilms and biocomplexity. Microbe. 2007;2(7):347-355.

Shi X, Zhu X. Biofilm formation and food safety in food industries. Trends Food Sci Technol. 2009;20(9):407-413.

Srey S, Park SY, Jahid IK, Oh SR, Han N, Zhang CY, Kim $\mathrm{SH}$, Cho JI, Ha SD. Evaluation of the removal and destruction effect of a chlorine and thiamine dilaurylsulfate combined treatment on L. monocytogenes biofilm. Foodborne Pathog Dis. 2014;11(8):658-663.

Stoporth JD, Samelis J, Sofos JN, Kendall PA, Smith GC. Biofilm formation by acid-adapted and non-adapted Listeria monocytogenes in fresh beef decontamination washings and its subsequent inactivation with sanitizers. J Food Protect. 2002;65(11):1717-1727.

Takahashi H, Kuramoto S, Miya S, Kimura B. Desiccation survival of Listeria monocytogenes and other potential foodborne pathogens on stainless steel surfaces is affected by different food soils. Food Control. 2011;22(3-4):633-637.

Tompkin RB. Control of Listeria monocytogenes in the foodprocessing environment. J Food Protect. 2002;65(4):709-725.

Van der Veen S, Abee T. Mixed species biofilms of Listeria monocytogenes and Lactobacillus plantarum show enhanced resistance to benzalkonium chloride and peracetic acid. Int $\mathrm{J}$ Food Microbiol. 2011;144(3):421-431.

Wang W, Zhou X, Suo Y, Deng X, Cheng M, Shi C, Xianming S. Prevalence, serotype diversity, biofilm-forming ability and eradication of Listeria monocytogenes isolated from diverse foods in Shanghai, China. Food Control. 2016 (in press).

Received for publication on $27^{\text {th }}$ September 2016 Accepted for publication on $21^{\text {st }}$ February 2017 